\title{
Anti-adhesion and antibacterial activity of silver nanoparticles and graphene oxide-silver nanoparticle composites
}

\author{
Sandra Gabriela Gómez de Saravia ${ }^{1,2}$, Silvia Elena Rastelli ${ }^{1,2}$, \\ Carolina Angulo-Pineda ${ }^{3}$, Humberto Palza ${ }^{3}$, \\ Marisa Rosana Viera ${ }^{1,4}$
}

\footnotetext{
${ }^{1}$ Centro de Investigación y Desarrollo en Tecnología de Pinturas (CIDEPINT), CICPBA-CONICET- FI, UNLP, 1900, La Plata, Buenos Aires, Argentina.

${ }^{2}$ Facultad de Ciencias Naturales y Museo, UNLP, Av.60, 1900, La Plata, Buenos Aires, Argentina.

${ }^{3}$ Laboratorio de Ingeniería de Polímeros, Facultad de Ciencias Físicas y Matemáticas, Universidad de Chile, A. Blanco Encalada 2085, Santiago, Santiago, Chile.

${ }^{4}$ Facultad de Ciencias Exactas, UNLP. Calle 47 esq.115, (1900), La Plata, Buenos Aires, Argentina. e-mail: s.gomez@cidepint.ing.unlp.edu.ar, e.rastelli@cidepint.ing.unlp.edu.ar, cangulo@u.uchile.cl,m.viera @ cidepint.ing.unlp.edu.ar
}

\begin{abstract}
The rise of nanotechnology has allowed the development of several inorganic nanoparticles with strong biocidal properties against bacteria, fungi, and viruses. Among them, silver nanoparticles (AgNPs) stand out as one of the most promising antimicrobial nanomaterials. Graphene oxide (GO) is another attractive nanomaterial with antimicrobial properties. Although the antimicrobial effect of AgNPs and GO is known, the development of hybrid materials of GO-AgNPs has considerable interest in various applications since they may exhibit synergistic bactericidal properties that exceed the yields of the individual components. The aims of this work were to evaluate the antimicrobial activity and anti-adhesion properties of AgNPs and GO-AgNPs nanocomposites for potential applications in antimicrobial coatings. The antimicrobial activity was tested by agar diffusion method. It was found that activity varied according to the synthesis procedure of the nanomaterials. Pseudomonas aeruginosa, Bacillus cereus and Kokuria rhizophila were the most susceptible strains. The nanocomposite GO- AgNPs synthetized using the ex-situ method exhibited the highest antibacterial activity against all the assayed strains. Similar results were obtained for bacterial adhesion inhibition tests. Thus, GO-AgNPs nanohybrids could be applied as antibacterial coatings to prevent bacterial biofilm development.
\end{abstract}

Keywords: Silver nanoparticles, graphene oxide, bacteria, biofilms.

\section{INTRODUCTION}

One of the most effective strategies for the prevention of microbial colonization is the development of functional materials with high antimicrobial properties. In this respect, the antimicrobial efficacy of nanoparticles (NPs), including metal and carbon-based NPs, has been widely studied [1-4].

Among the great variety of antibacterial materials, silver NPs (AgNPs) are marked out as antimicrobial reagents with high capability due to their large surface area and slow release properties [5-8]. They have been used as biocide agents in biomedicine, food, cosmetic and textile applications [9-13] and the responsible mechanism is not yet completely clarified [14,15]. There are studies that point out different cellular targets and actions such as: disturbance of the cell membrane, alteration of cellular DNA and proteins, electron transport, nutrient uptake, protein oxidation, or membrane potential; or the generation of reactive oxygen species (ROS), which lead to cell death. [14, 16, 17]. Despite the proven efficacy of AgNPs, they can lose antibacterial activity due to self-aggregation or precipitation [18]. These problems could be avoided by using graphene or graphene oxide as supporting matrix for the AgNPs [19].

Graphene is a two-dimensional material composed of a hexagonal sp2-hybridized carbon network $[20,21]$ giving a large superficial area, while graphene oxide (GO) is a chemically modified graphene featuring hydroxyl, carboxyl and epoxy functional groups [22]. Graphene-based materials are attractive 
nanomaterials because of their unique chemical, physical, electric, mechanical, thermal and antimicrobial properties which made them useful for several applications such as biomedical, energy, nanoelectronic, biosensors, among others [20-24].

Accordingly, silver nanoparticles assembled on graphene oxide sheets (GO-AgNPs) have been exploited as novel antibacterial systems [25,26] exhibiting antibacterial activity against Gram-negative Escherichia coli. Also, in-situ synthesis of GO-AgNPs with good antibacterial activity has been extensively reported $[27,28]$. However, the potential for these nanocomposites to prevent biofilm formation has not been explored. Thus, the aim of this work was to evaluate the antimicrobial activity and antiadhesion properties of AgNPs and GO-AgNPs nanocomposites for potential applications in antimicrobial coating formulations.

\section{MATERIALS AND METHODS}

\subsection{Synthesis and characterization of the nanocompounds}

Hummers and Offeman method was used to obtain GO as reported in GARZON et al. [29]. Ten milligrams of GO were suspended in $30 \mathrm{ml}$ of deionized water by ultrasonic bath resulting in a colloidal suspension. Hybrid GO-AgNPs were obtained by two routes of synthesis. The first one was ex-situ, using reducing agent of silver nitrate solution (Merck®) and gelatin solution (Sigma Aldrich®) as a stabilizing and reducing agent as in ZHANG et al. [30]. The second route was in-situ synthesis where AgNPs were nucleated and grown on GO sheets. A homogenous solution of GO was mixed with a silver nitrate solution. After that, the temperature was raised to $100^{\circ} \mathrm{C}$. At this time, sodium citrate was added dropwise until the solution turned gray, as described in FONSECA DE FARIA et al. [31]. In both cases, the particle synthesis was evaluated by UV-visible measurements (200-600nm) which were recorded using a Rayleigh UV1601 UV/VIS-spectrophotometer. Micrographs of nanohybrids were obtained by transmission electron microscope (TEM)-(TECNAIG) operated at $200 \mathrm{kV}$.

\subsection{Antimicrobial activity}

The antimicrobial activity of the AgNPs and GO-AgNP nanocomposites was evaluated using the agar diffusion method (Kirby-Bauer method) [32]. These screening was carried out against Gram-positive and Gram-negative bacteria: Pseudomonas aeruginosa PAO 1, Escherichia coli (ATCC11229), Acinetobacter sp. (KM349193, NCBI-GenBank), Bacillus cereus (ATCC 10876), Staphylococcus sp. and Kocuria rizophila (ATCC 9341). Inocula were prepared in Muller-Hinton (M-H) broth, from fresh $24 \mathrm{~h}$ cultures, all with an $\mathrm{OD}_{\mathrm{i}(600 \mathrm{~nm})} \approx 0.1\left(\approx 10^{8} \mathrm{CFU} \cdot \mathrm{ml}^{-1}\right)$. M-H agar plates were inoculated by swab, in three directions, except for Staphylococcus sp., which was seeded by spreading $200 \mu$ l of the culture with a Drigalsky spatula. Three sterile filter paper disks were placed on each plate. On the filter paper, $10 \mu \mathrm{l}$ of each nanomaterial was poured. The plates were incubated $20 \mathrm{~h}$ at $30 \pm 2{ }^{\circ} \mathrm{C}$. The inhibition zones were measured considering: $\leq 6 \mathrm{~mm}$ null antibacterial activity and $>6 \mathrm{~mm}$ positive antibacterial activity. The assay was performed in triplicate.

\subsection{Coating deposition}

AISI 430 stainless steel (SS) coupons, previously sterilized with UV light, were immersed in AgNPs and nanohybrid solutions for $24 \mathrm{~h}$ at $4{ }^{\circ} \mathrm{C}$, in darkness to form a coating. Then, coupons were removed from the solutions and dried in the laminar flow bench. The contact angle of the SS coupons without and with the different coatings was measured by the drop method using an optical microscope with an image analyzer.

\subsection{Bacterial adhesion inhibition test}

Inhibition of bacterial adhesion on AISI 430 SS coupons was evaluated in multi-well plates. In each well, $1 \mathrm{ml}$ of the $\mathrm{P}$. aeruginosa inoculum with an $\mathrm{ODi}_{(600 \mathrm{~nm})} \approx 0.1(\approx 108 \mathrm{CFU} \cdot \mathrm{ml}-1)$ and coupons with and without coatings were placed. After $24 \mathrm{~h}$ at $30 \pm 2{ }^{\circ} \mathrm{C}$ the coupons were drawn from the culture and rinsed with sterile distilled water. Then, one coupon of each condition was scrapped with sterile scalpel in $1 \mathrm{ml}$ of physiologic solution, and serial dilutions were seeded in nutrient agar plates to perform bacterial counts. 


\subsection{SEM observations}

Coupons with and without coatings, before and after the exposure to the $P$. aeruginosa culture were observed in the scanning electron microscopy (SEM) (FEI Quanta 200, ThermoFisher, USA). Prior to SEM observations, samples were fixed in $2.5 \% \mathrm{v} / \mathrm{v}$ glutaraldehyde in phosphate-buffered saline (PBS), dehydrated in ethanol (from 20 to 100\% concentration) and metalized with Au.

\section{RESULTS AND DISCUSSION}

\subsection{Synthesis and characterization of the nanocompounds.}

Figure 1 shows UV-visible spectra of AgNPs (a) and the GO-AgNPs aggregates synthetized via the exsitu (b) or in-situ (c) method. Figure 1a) shows the UV-visible spectrum of the AgNPs synthetized with gelatin, which is comparable with the literature where the spherical AgNPs have a peak of absorbance between the range 420-480 $\mathrm{nm}$ depending on the shape [30,33]. Figure 1b) shows the characteristic peak of AgNPs but with less intensity than the UV spectra in Figure 1a), due to the presence of GO in the sample [30]. In the case of GO-AgNPs in-situ, it was possible to observe the characteristic peaks of both nanomaterials, as indicated in Figure 1c). Around 250-300 nm, the typical motion in $\mathrm{C}=\mathrm{O}$ bonds from $\mathrm{n}-\pi$ transition in the GO was obtained. In contrast to ex-situ synthesis, only the AgNPs peak was observed. TEM micrographs in Figures $1 \mathrm{~d}$ ); 1 e) and $1 \mathrm{f}$ ) confirm the spherical and Ag NPs attached on GO sheets were obtained, as shown in figures $1 \mathrm{e}$ ) and $\mathrm{f}$ ).

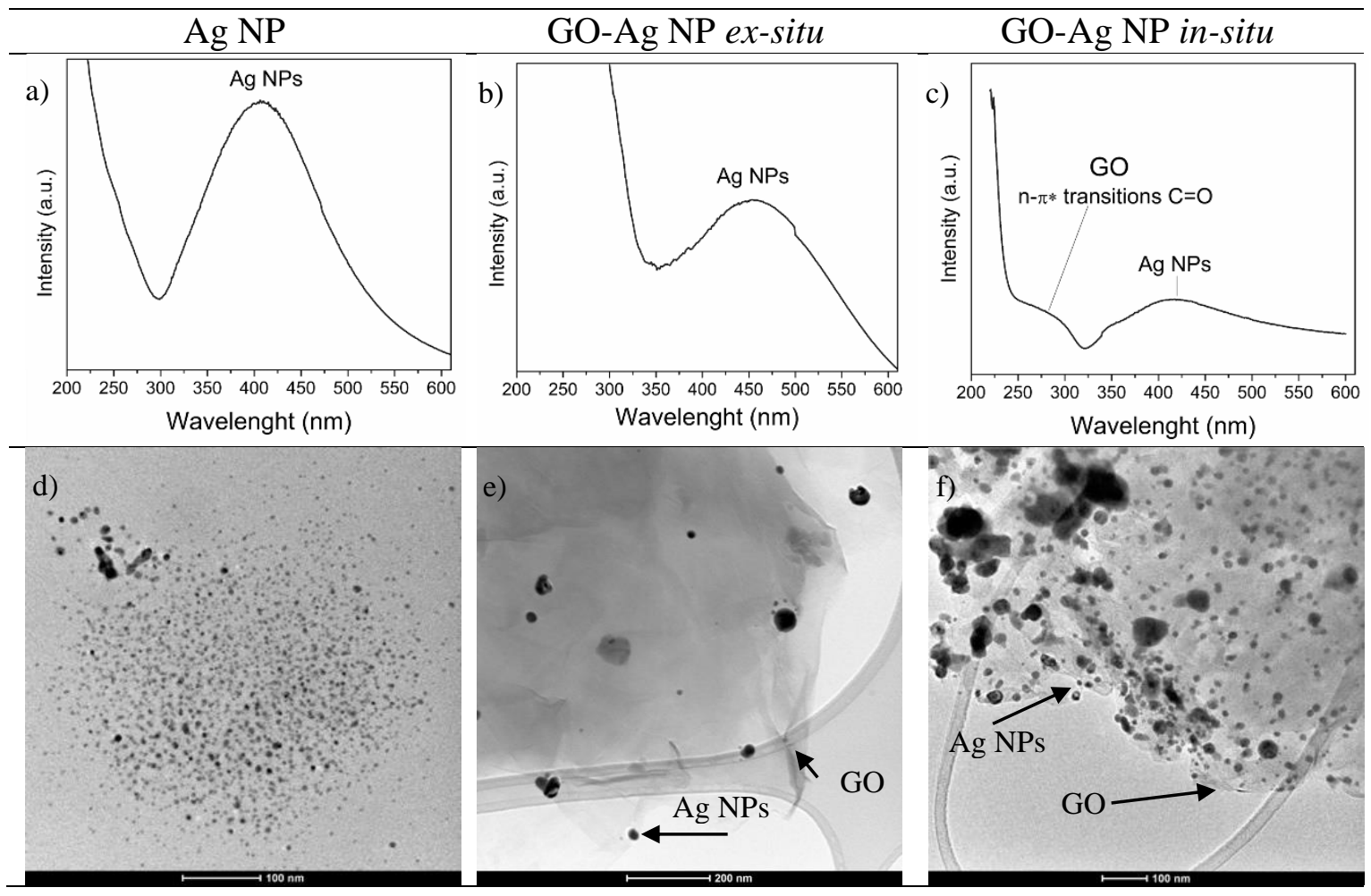

Figure 1: UV-visible spectra and TEM images: a) and d): AgNPs; b) and e): GO-AgNPs $e x-s i t u$, c) and f): GOAgNPs in-situ.

\subsection{Antimicrobial activity of AgNPs and GO-AgNPs nanocomposites}

All the nanomaterials showed a certain degree of antibacterial activity as it can be seen in some of the plates used in the diffusion test (Figure 2). The average size of the inhibition zone measured for all the strains is presented in Figure 3. P. aeruginosa and $K$. rizophila were the most susceptible strains. The nanocomposite GO-AgNPs synthetized using the $e x$-situ method exhibited the highest antibacterial activity against all the assayed strains. Similar results regarding the enhanced antibacterial activities of GOAgNPs vs. AgNPs were also reported by ZHANG et al. [34] who studied their effect against both Gramnegative Escherichia coli and Gram-positive Bacillus subtilis. 


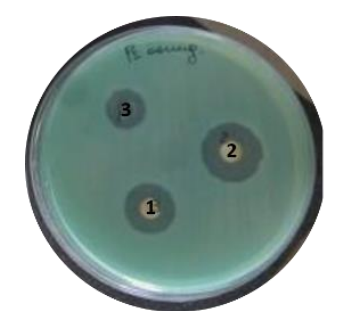

Pseudomonas aeruginosa

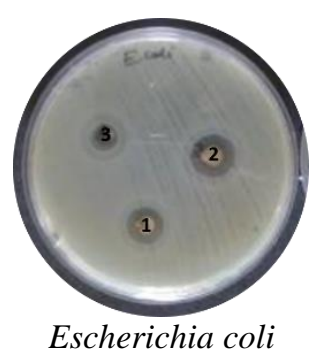

Escherichia coli

Figure 2: Photograph of one plate seeded with $P$. aeruginosa (left) and one seeded with $E$. coli (right) showing the inhibition zones produced by AgNPs (1), GO-AgNPs ex-situ (2) and GO-AgNPs in-situ (3).

The different susceptibilities to AgNPs may be due to different cell wall structures and the different antibacterial mechanisms of $\mathrm{Ag}$ against different cells [35-37]. For instance, Gram-negative bacteria possess a thin peptidoglycan layer (7-8 $\mathrm{nm}$ thickness), whereas Gram-positive bacteria possess a thick peptidoglycan layer (about 20-80 nm thickness) [38], which is more resistant to $\mathrm{Ag}^{+}$diffusion.

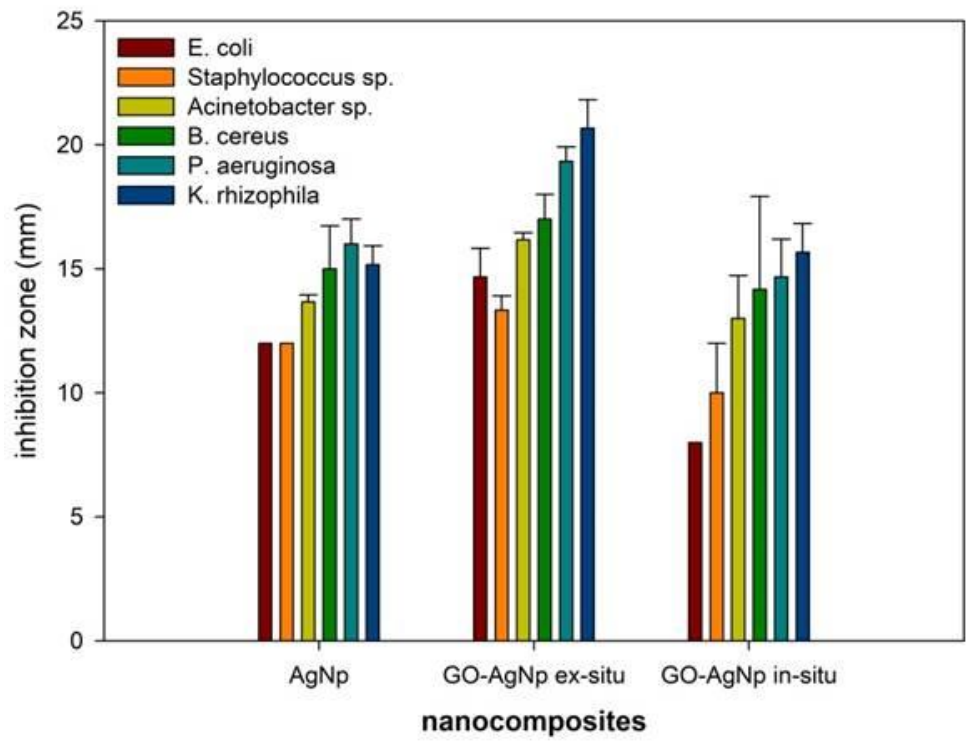

Figura 3: Inhibition zone (mm) of the AgNPs and the nanocomposites GO-AgNps ex-situ and GO-AgNPs in-situ against all tested bacterial strains.

\subsection{Bacterial adhesion inhibition test}

Before the adhesion test, the surface of the coated and uncoated SS coupons was characterized through water contact angle (WCA) measurements (Figure 4) and SEM observations (Figure 5). The WCA of the clean SS coupon and those coated with the nanomaterials did not show significant differences. WCA values smaller than $90^{\circ}$ are characteristic of hydrophilic surfaces with good wettability and adhesion and high surface energy [39]. These surfaces are more able to bind bacteria or cells, as compared with extremely hydrophobic or hydrophilic surfaces [40]. It has been reported that surface with WCA between 40 to $70^{\circ}$ enhanced cell adhesion and growth [41]. From the above, it can be assumed that the materials tested in this work would allow the development of bacterial biofilms. 
430 AISI SS coupon without coating

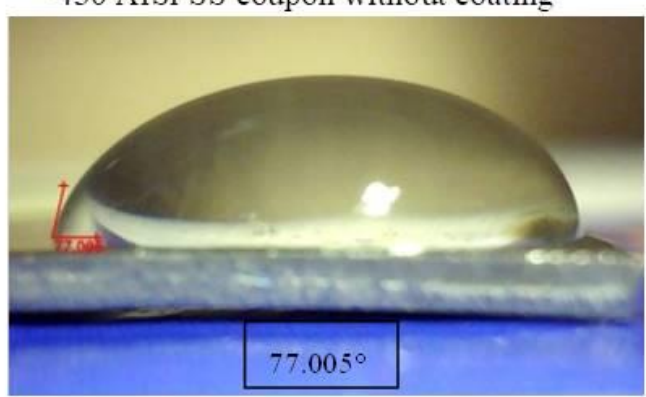

430 AISI SS coupon with GO-AgNPs

$($ ex-situ $)$

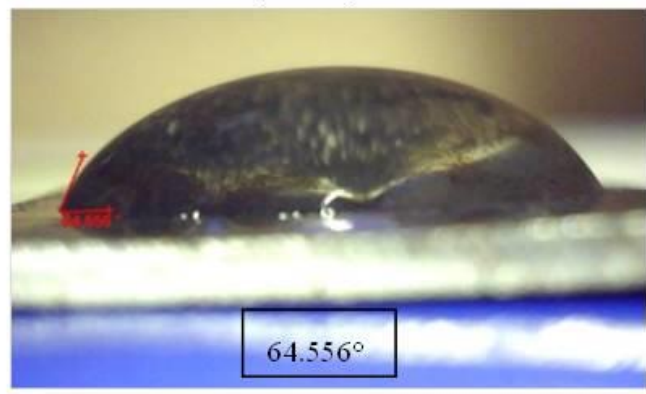

430 AISI SS coupon with AgNPs

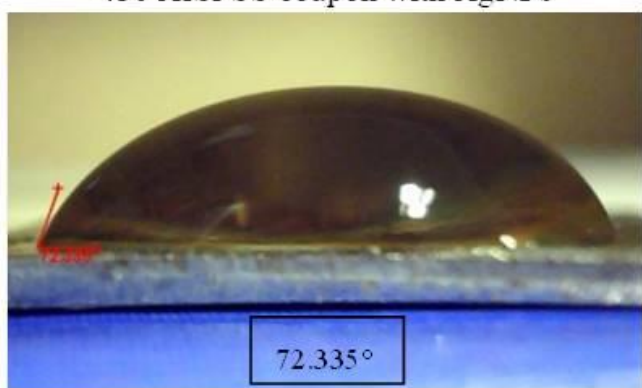

430 AISI SS coupon with GO-AgNPs (in-situ)

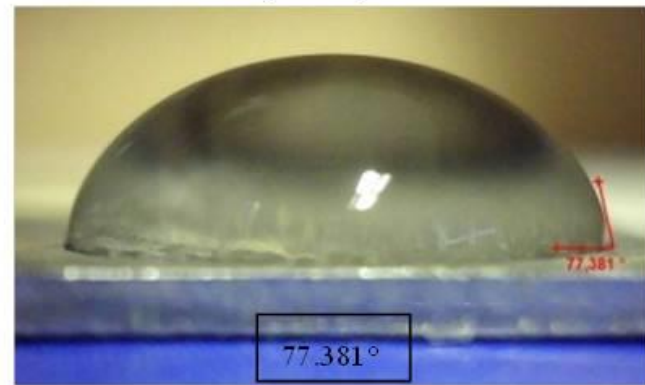

Figure 4: Water drop on the SS surfaces without and with coatings for contact angle measurements. The values of the contact angle obtained are indicated in each photograph.
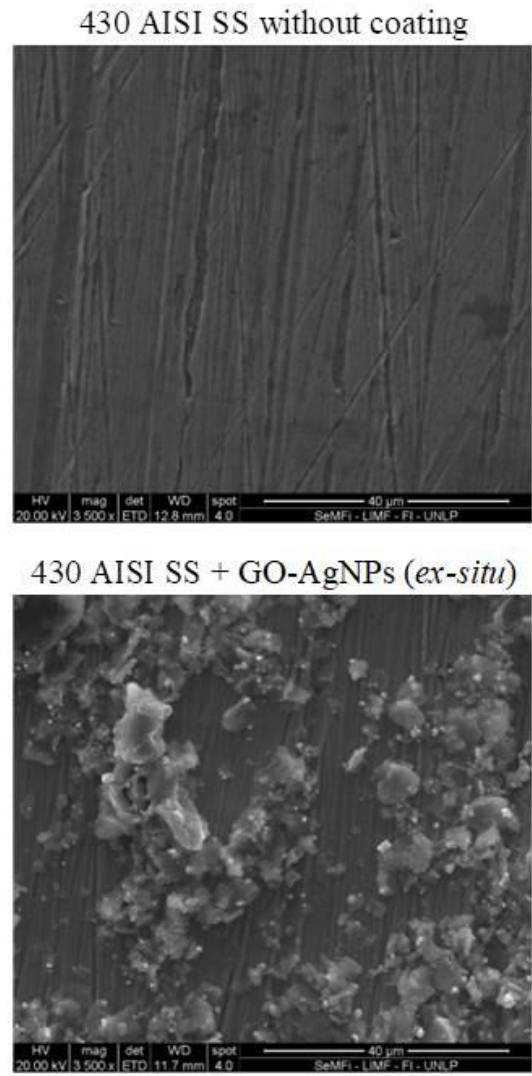

430 AISI SS + AgNps
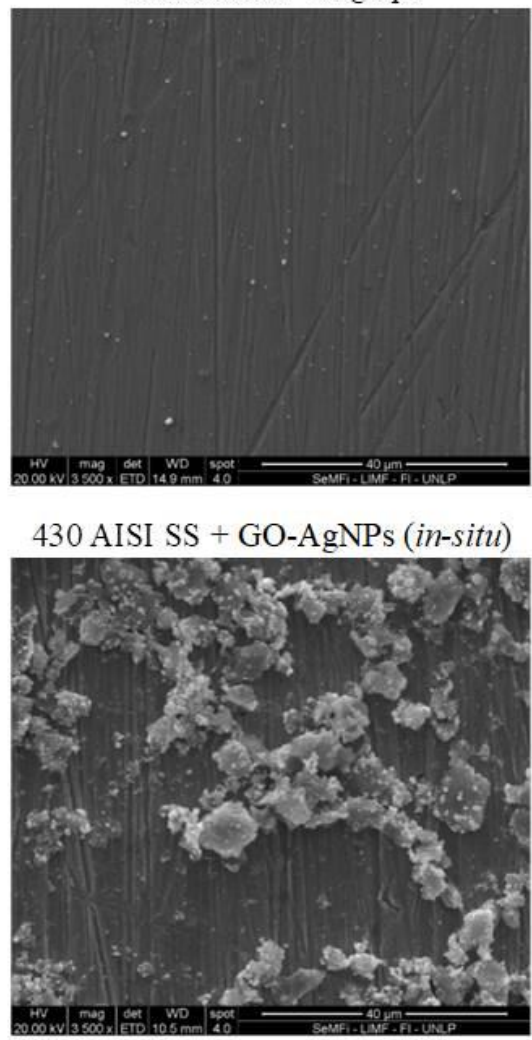

Figure 5: Microphotographs of SEM images of the SS coupons uncoated and coated with the different nanomaterial, before the bacterial adhesion test. 
The number of $P$. aeruginosa cells adhered on the coupons were $10^{5}-10^{6} \mathrm{CFU} \cdot \mathrm{cm}^{-2}$ for control coupons, $10^{4}-10^{5} \mathrm{CFU} . \mathrm{cm}^{-2}$ for GO-AgNPs (in-situ) coupons and values lower than $10^{2} \mathrm{CFU} . \mathrm{cm}^{-2}$ on AgNPs and GO-AgNPs (ex-situ) coupons, indicating that the later materials possessed antifouling activity. These results were corroborated by the SEM observations (Figure 6). GO-AgNPs suspensions were reported to inhibit $100 \%$ of $P$. aeruginosa cells adhered to stainless steel surface after $1 \mathrm{~h}$ of contact between the supported cells and the nanohybrid material suspended in the culture medium [31]. In our study, the nanomaterials immobilized on the SS surface, provoked a decrease in the number of attached bacteria. However a complete inhibition of biofilm formation or the death of all the bacteria was not observed. Although most of the studies note the importance of dissolved silver ions in the antibacterial effect, several reports claim that leaching silver ions alone cannot account for the silver nanoparticles' cytotoxicity. The size and morphology of the nanoparticles also affect the biocidal performance [42].
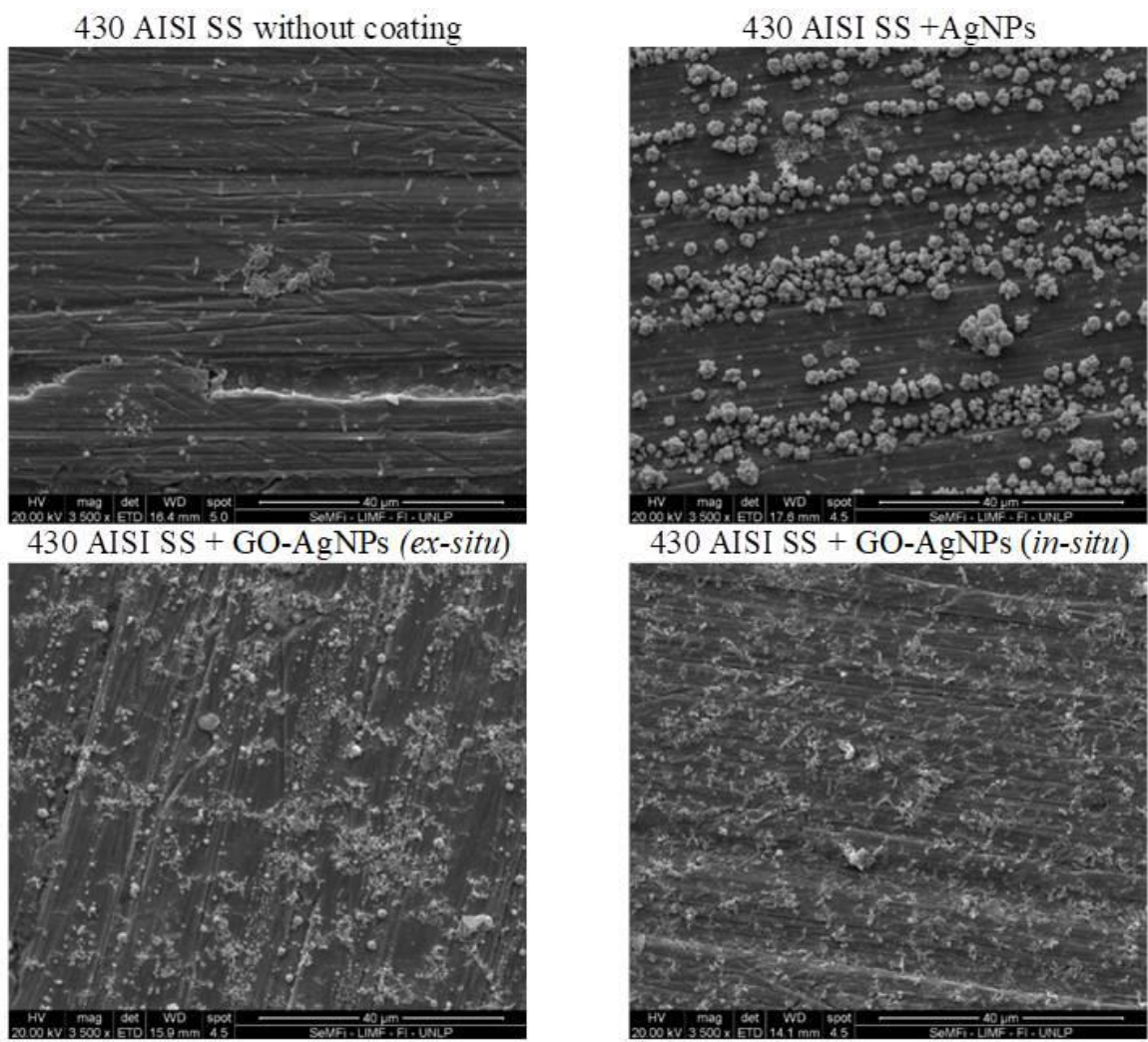

Figure 6: Microphotographs of SEM images of the SS coupons uncoated and coated with the different nanomaterial, after the immersion in P. aeruginosa culture. In all the cases, the magnification is $3500 \mathrm{x}$ and the scale bar $40 \mu \mathrm{m}$.

One advantage of the GO sheets is its role as a supporting and stabilizing agent, and the bacterial activity reduction [31]. The graphene nanosheets are able to wrap around of the bacteria cell maximizing the contact area between the AgNPs material and the bacteria. In addition, graphene material allows the formation of Ag NPs on its surface and minimizes Ag NPs agglomeration, enhancing the biocidal activity of metallic silver [43].

On the other hand, the use of nanomaterials as antimicrobial agents is associated with the bacterial resistance. The excessive use of the conventional disinfectants to control biofilm formation may lead to bacterial strains that are resistant to the chemical substance applied due to the defense mechanism the bacteria have created. GO-AgNPs could be used as an alternative anti-biofilm agent without the adverse effects of microbial resistance frequently attributed to antibiotics, disinfectants and other conventional agents [44].

\section{CONCLUSIONS}

All the nanomaterials assayed showed antibacterial activity against planktonic bacteria. The nanocompo- 
site GO-AgNPs synthetized using the ex-situ method exhibited the highest antibacterial activity against all the assayed strains.

$K$. rhizophila, $P$. aeruginosa and $B$. cereus were the most susceptible strains.

The namomaterials were also able to reduce the number of bacteria attached to the SS coupons. AgNps and GO- AgNps (ex situ) produced a reduction of three orders of magnitude in the number of bacteria attached.

The results support the idea that GO-AgNps nanocomposites may be added in antimicrobial paint and coating formulations to diminish the development of biofilms.

\section{ACKNOWLEDGEMENTS}

The authors are grateful the National University of La Plata Project 11/ I238, CONICET PIP No. 00314 and CICBA 195/17 for the grants received to finance this work. The authors thank Eng. Pablo Seré (from Lab. Anelpire, CIDEPINT) for the contact angle measurements.

\section{BIBLIOGRAPHY}

[1] BAI, H., LIU, Z., SUN, D.D., "Hierarchical $\mathrm{ZnO} / \mathrm{Cu}$ "corn-like" materials with high photodegradation and antibacterial capability under visible light", Physical Chemistry Chemical Physics, v. 13, n. 13, pp. 6205-6210, Feb.2011.

[2] LIANG, X., SUN, M., LI, L., et al., "Preparation and antibacterial activities of polyaniline/Cu0.05Zn0.95O nanocomposites", Dalton Transactions, v. 41, n. 9, pp. 2804-2811, Mar. 2012.

[3] LIU, S., ZENG, T.H., HOFMANN, M., et al., "Antibacterial activity of graphite, graphite oxide, graphene oxide, and reduced graphene oxide: membrane and oxidative stress", ACS Nano, v. 5, n. 9, pp. 6971-6980, Sep. 2011.

[4] LIU, S., HU, M., ZENG, T.H., et al., "Lateral dimension-dependent antibacterial activity of graphene oxide sheets", Langmuir, v. 28, n. 33, pp. 12364-12372, Aug. 2012.

[5] TAGLIETTI, A., DIAZ FERNANDEZ, Y.A., AMATO, E., et al., "Antibacterial activity of glutathione-coated silver nanoparticles against Gram-positive and Gram-negative bacteria", Langmuir, v. 28, n. 21, pp. 8140-8148, May. 2012.

[6] SANPUI, P., MURUGADOSS, A., PRASAD, P.V., et al., "The antibacterial properties of a novel chitosan-Ag-nanoparticle composite", International Journal Food Microbiology, v. 124, n. 2, pp. 142-146, May. 2008.

[7] CUI, J., HU, C., YANG, Y., et al., "Facile fabrication of carbonaceous nanospheres loaded with silver nanoparticles as antibacterial materials", Journal of Material Chemistry, v. 22, n. 16, pp. 8121-8126, Mar. 2012.

[8] RAI, M., YADAV, A., GADE, A., "Silver Nanoparticles as a New Generation of Antimicrobials", Biotechnology Advances, v. 27, n. 1, pp. 76-83, Sep. 2008.

[9] EL-NOUR, K.M.M.A., EFTAIHA, A., AL-WARTHAN, A., et al., "Synthesis and appli-cations of silver nanoparticles", Arabian Journal of Chemistry, v.3, n.3, pp. 135-140, Jul. 2010.

[10] KATZ, L.M., DEWAN, K., BRONAUGH, R.L., "Nanotechnology in cosmetics", Food and Chemical Toxicology, v. 85, pp.127-137. Nov. 2015.

[11] WEI, L., LU, J., XU, H., et al., "Silver nanoparticles: synthesis, properties, and therapeutic applications”, Drug Discovery Today, v. 20, n. 5, pp. 595-601, May. 2015.

[12] KOIZHAIGANOVA, M., YAŞA, I., GÜLÜMSER, G., “Assessment of antibacterial activity of lining leather treated with silver doped hydroxyapatite", International Biodeterioration \& Biodegradation, v. 105, pp. 262-267. Nov. 2015.

[13] JUNG, W.K., KOO, H.C., KIM, K.W., et al., "Antibacterial activity and mechanism of action of the silver ion in Staphylococcus aureus and Escherichia coli", Applied Environmental Microbiology, v. 74, n. 7, pp. 2171-2178, Apr. 2008.

[14] SINGH, A.K., "Structure, synthesis, and application of nanoparticles", In Engineered Nanoparticles. Structure, Properties and Mechanisms of Toxicity, chapter 2, USA, Academic Press, Copyright (C) 2016 
Elsevier Inc. All rights reserved. https://doi.org/10.1016/B978-0-12-801406-6.00002-9.

[15] WHO, Guidelines for Drinking-water Quality, Health Criteria and Other Supporting Information. Second ed., v. 2. pp. 15, 1996.

[16] LOK, C., HO, C., CHEN, R., et al., "Proteomic analysis of the mode of antibacterial action of silver nanoparticles", Journal of Proteome Research, v. 5, n. 4, pp. 916-924, Apr. 2006.

[17] MORONES, J.R., ELECHIGUERRA, J.L., CAMACHO, A., et al., "The bactericidal effect of silver nanoparticles", Nanotechnology, v. 16, n. 10, 2346-2353, Aug. 2005.

[18] KONG, H, JANG, J., "Antibacterial properties of novel poly(methyl methacrylate) nanofiber containing silver nanoparticles", Langmuir, v.24, n. 5, pp. 2051-2056, Jan. 2008.

[19] YANG, H., LIU, Y., SHEN, Q., et al., "Mesoporous silica microcapsule-supported Ag nanoparticles fabricated via nano-assembly and its antibacterial properties", Journal of Material Chemistry, v. 22, pp. 24132-24138, Oct. 2012.

[20] SOLDANO, C., MAHMOOD, A., DUJARDIN, E., "Production, properties and potential of graphene", Carbon, v. 48, n. 8, pp. 2127-2150, Jul. 2010.

[21] RAO, C.N.R., SOOD, A.K., et al., "Graphene: the newtwo-dimensional nanomaterial", Angewandte Chemie International Edition, v. 48, n.42, pp. 7752-7777, Sept. 2009.

[22] LI, J., LIU, C., "Ag-grapheneheterostructures: synthesis, characterization and optical properties", European Journal of Inorganic Chemistry, v. 2010, n. 8, pp. 1244-1248, Mar. 2010

[23] YANG, K., ZHANG, S., ZHANG, G.X., et al., "Graphene in mice: ultrahighin vivo tumor uptake and efficient photothermal therapy", Nano Letters, v. 10, n. 9, pp. 3318-23, Sept. 2010.

[24] WU, C.Y., ZHANG, Y., WU, X.C., et al., "Biological applications ofgraphene and graphene oxide", Nano Biomedicine and Engineering, v. 4, n. 4, pp. 157-162, 2012.

[25] LIU, L., WANG, Y., YAN, X., et al., "Facile synthesis of monodispersed silver nanoparticles on graphene oxide sheets with enhanced antibacterial activity", New Journal of Chemistry, v. 35, n. 7, pp. 1418-1423, Apr. 2011.

[26] DAS, M.R., SARMA, R.K., SAIKIA, R., et al., "Synthesis of silver nanoparticles in an aqueous suspension of graphene oxide sheets and its antimicrobial activity", Colloids and surfaces. B, Biointerfaces, v. 83, n. 1, pp. 16-22, Oct. 2010.

[27] MA, J. , ZHANG, J., XIONG, Z., et al., "Preparation, characterization and antibacterial properties of silver-modified graphene oxide", Journal of Materials Chemistry, v.21, n. 10, pp. 3350-3352, Feb. 2011.

[28] TANG, J., CHEN, Q., XU, L., et al., "Graphene Oxide-Silver Nanocomposite As a Highly Effective Antibacterial Agent with Species-Specific Mechanisms", ACS Applied Material Interfaces, v. 5, n.9, pp. 3867-3874, Apr. 2013.

[29] GARZON, C., WILHELM, M., ABBASI M., et al., "Effect of carbon-based particles on the mechanical behavior of isotactic poly(propylene)s", Macromolecular Materials and Engineering, v. 301, n.4, pp. 429-440, Apr. 2016.

[30] ZHANG, D., LIU X., WANG, X., "Green synthesis of graphene oxide sheets decorated by silver nanoprisms and their anti-bacterial properties", Journal of Inorganic Biochemistry, v. 105, pp. 1181-1186, Sept. 2011.

[31] FONSECA DE FARIA, A., MARTINEZ, D., MEIRA, S., et al., "Anti-adhesion and antibacterial activity of silver nanoparticles supported on graphene oxide sheets", Colloids and Surfaces, B, Biointerfaces, v. 113, pp. 115-124, Jan. 2014.

[32] BAUER, A.W., KIRBY, W.M.M., SHERRIS, J.C., et al., "Antibiotic susceptibility testing by a standardized single disk method", American Journal of Clinical Pathology, v. 45, n. 4, pp. 493-496, Apr. 1966.

[33] SILVA, J.N., SAADE, J., FARIAS, P.M.A., et al., "Colloidal Synthesis of Silver nanoprisms in aqueous medium: influence of chemical compounds in uv/vis absorption spectra", Advances in Nanoparticles, v. 2., n. 3, pp. 217-222, Aug. 2013.

[34] ZHANG, H., GRÜNER, G., ZHAO, Y., "Recent advancements of graphene in biomedicine", Journal of Material Chemistry B, v. 20, pp. 2542-2567, Apr. 2013.

[35] JIN, X., LI, M., WANG, J., et al., "High-throughput screening of silver nanoparticle stability and bacterial inactivation in aquatic media: influence of specific ions", Environmental Science \& Technology, v. 44, n. 19, pp. 7321-7328, Jul. 2010. 
[36] MARTÍNEZ-CASTAÑÓN, G.A., NIÑO-MARTÍNEZ, N., MARTÍNEZ-GUTIERREZ, F., et al., "Synthesis and antibacterial activity of silver nanoparticles with different sizes", Journal Nanoparticle Research, v. 10, n. 8, pp. 1343-1348, Dec. 2008.

[37] BANERJEE, M., SHARMA, S., CHATTOPADHYAY, A., et al., "Enhanced antibacterial activity of bimetallic gold-silver core-shell nanoparticles at low silver concentration", Nanoscale, v.3, n.11, pp. 5120-5125, Jun. 2011.

[38] KUMAR, A., VEMULA, P.K., AJAYAN, P.M., et al., "Silver-nanoparticle-embedded antimicrobial paints based on vegetable oil", Nature Material, v. 7, pp. 236-241, Jan. 2008.

[39] BUSSCHER, H.J., WEERKAMP, A.H., VAN DER MEI, H.C., et al., "Measurement of the surface free energy of bacterial cell surfaces and its relevance for adhesion", Applied and Environmental Microbiology, v. 48, n. 5, pp. 980-983, Nov. 1984.

[40] ZHANG, X., WANG, L., LEVÄNEN, E., "Superhydrophobic Surfaces for the Reduction of Bacterial Adhesion", RSC Advances, v. 3, pp. 12003-12020, Aug. 2013.

[41] LEE, J.H., LEE, H.B., LEE, J.W., et al., "Interaction of Different Types of Cells on Polymer Surfaces with Wettability Gradient”, Journal of Colloid and Interface Science, v. 205, pp. 323-330, Sept. 1998.

[42] DURÁN, N., DURÁN, M., JESUS, M.B., et al., "Silver nanoparticles: A new view on mechanistic aspects on antimicrobial activity", Nanomedicine: Nanotechnology, Biology and Medicine, v. 12, pp. 789799, Dec. 2016.

[43] YEE, M.S.-L., KHIEW, P.-S., CHIU, W.S., et al., "Green synthesis of graphene-silver nanocomposites and its application as a potent marine antifouling agent", Colloids and Surfaces B: Biointerfaces, v. 148, pp. 392-401, Dec. 2016.

[44] ROE, D., KARANDIKAR, B., BONN-SAVAGE, N., et al., Antimicrobial surface functionalization of plastic catheters by silver nanoparticles", Journal Antimicrobial Chemotherapy, v.61, n. 4, pp. 869876, Feb. 2008.

\section{ORCID}

Sandra Gabriela Gómez de Saravia

Silvia Elena Rastelli

Carolina Angulo-Pineda

Humberto Palza

Marisa Rosana Viera https://orcid.org/0000-0002-3025-6176

https://orcid.org/0000-0003-4709-2021

https://orcid.org/0000-0002-6760-5659

https://orcid.org/0000-0001-5246-6791

https://orcid.org/0000-0003-4705-7824 